Historic, archived document

Do not assume content reflects current scientific knowledge, policies, or practices. 



\section{A99.9 \\ F7624U}

station

$4=2,12+242$

Serial Library

$$
\begin{gathered}
\text { RESEARCH PAFER LS-2 } \\
\text { January } 1963
\end{gathered}
$$

Fonest Soil Freezing

and the

Influence of Management

Practices, Nonthenn Minnesota

Sidney Weitzman

Roger R. Bay

LAKE STATES FOREST EXPERIMENT STATION

M. B. Dickerman, Director

FOREST SERVICE

U. S. DEPARTMENT OF AGRICULTURE 


\section{CONTENTS}

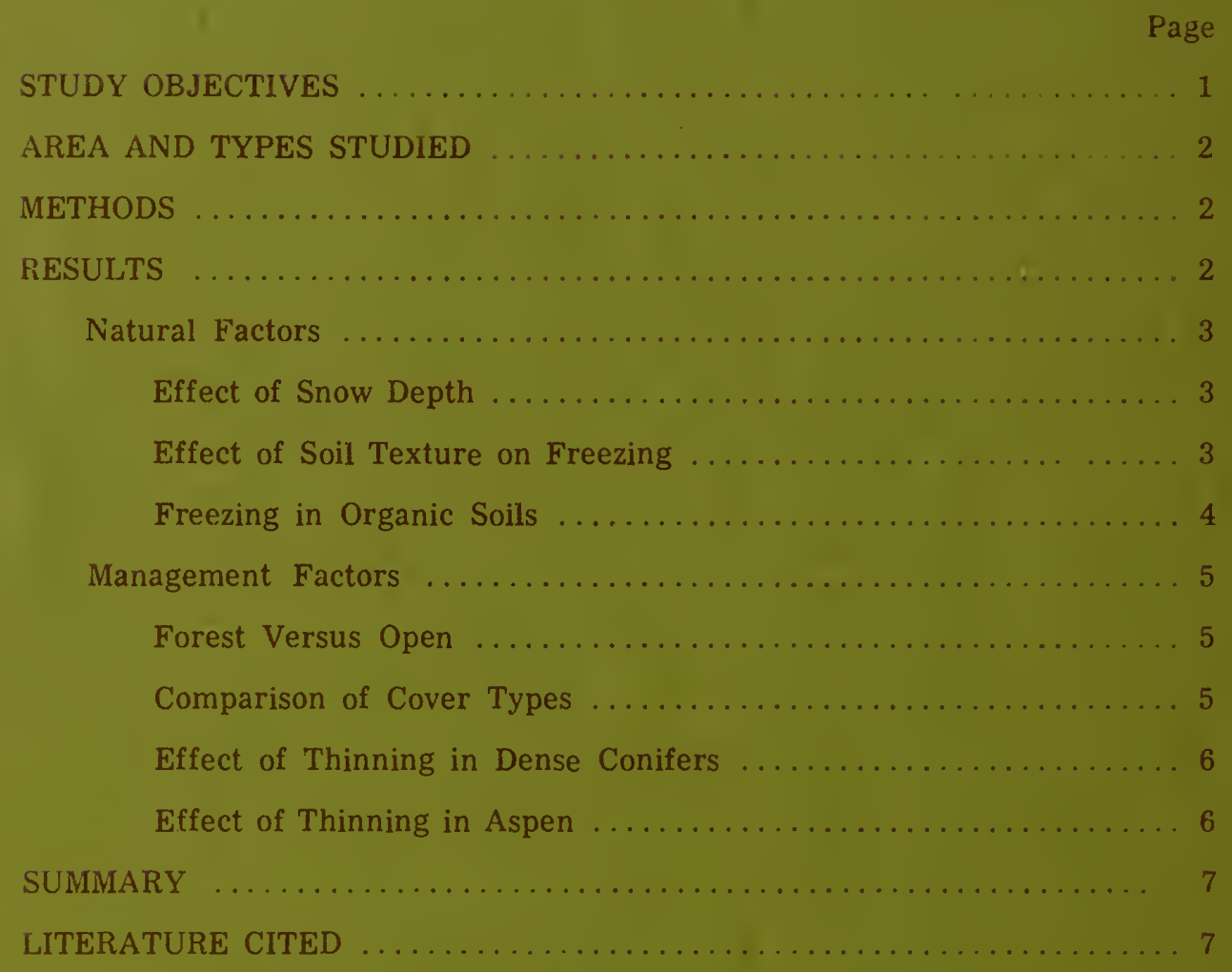

\section{FOR YOUR REFERENCE FILE}

Four abstract cards are included at the back of this report for the reader's convenience. 


\title{
Forest Soil Freezing and the Influence of Management Practices, Northern Minnesota
}

\author{
By \\ Sidney Weitzman and Roger R. Bay
}

How the forest affects water behavior is now under study as part of an overall program of watershed research in the Lake States. In this northern climate, soil freezing is an important phase of the hydrologic cycle: The presence and character of frost in the ground determine whether water enters the soil or runs off the surface (Augustine 1941, Coleman 1953). ${ }^{1}$

One frost type, known as concrete frost, limits the infiltration of snowmelt during winter and early spring thaws (Stoeckeler and Weitzman 1960, Trimble et al. 1958). Severe spring floods and erosion have been attributed to precipitation on frozen ground (Storey 1955). The floods of 1950 in the Upper Mississippi and Lake Superior basins, which caused damage estimated at 5 million dollars, came during heavy rains on a snowpack covering frozen ground (U.S. Dept. Int. 1953). In northern Minnesota, as much as 50 percent of the total annual runoff normally occurs in a 2-month period in early spring when the ground may still be frozen.

To get some background on frost behavior in the forests of northern Minnesota, the depth and occurrence of concrete frost were observed during two winters, 1957 and 1958. Three locations that cover a range of soil cover conditions were selected to learn something of the distribution of forest frost in the area.

\section{STUDY OBJECTIVES}

Earlier sudies show that concrete frost occurs less frequently, does not last as long, and is not as deep in a forest as in soils on open-land areas (Bay 1960, Bay et al. 1952, Hale 1950). However, the influence of the many cover types in the Lake States, the influence of local management practices, and the nature of underlying soils have not been adequately considered.

The major purpose of this study was to observe the incidence and depth of soil freezing at three selected areas that present a range of soil-cover conditions in northern Minnesota. This was an important first step since there have been large-scale changes in land use in that area. On approximately 38 percent of the land in the State, forest cover has been removed and converted to open land

Note: Mr. Weitzman is Chief of the Watershed Management Division of the Lake States Forest Experiment Station. Mr. Bay is a Research Forester at the Station's Silviculture and Watershed Management Laboratory at Grand Rapids, Minn.

1 Names and dates in parentheses refer to "Literature Cited" at the cnd of this report.
(Cunningham et al. 1958). Other cover types have been radically altered from pure pine and mixed pine-hardwood to aspen and aspen-brush. Do these changes modify the incidence of concrete frost? If so, what changes in cover are needed to reduce the incidence of concrete frost?

At the same time the role of other factors that affect soil freezing, such as the nature of the underlying soil, was observed. It is well established that in unfrozen conditions the soil is a key factor in water behavior. Does soil, in conjunction with cover, also play an important role in soil freezing? Snow depth was another factor studied, since it influences freezing and can be manipulated by forest practices.

Lastly, the influence of forest practices, such as thinning and reforestation, on soil freezing was observed.

The results, presented here, will help to enlarge our understanding of how forest practices and watershed management are interrelated locally. 


\section{AREA AND TYPES STUDIED}

Soil freezing was observed under different forest and soil conditions characteristic of northern
Minnesota. The 18 plots studied, all located either on or adjacent to experimental forests, are listed below:

\section{Experimental forest}

Pike Bay

Cutfoot Sioux

Big Falls
Soil texture

Very fine sandy loam to silt loam over clay loam till (Nebish-Rockwood series)

Deep loamy fine sand (Menahga series)

Loamy fine sand to medium sand

Organic peat soil

\section{Cover type and treatment}

Aspen-80 sq. ft. basal area per acre Aspen-65 sq. ft. basal area per acre White pine-hardwood

Balsam fir

Red pine plantation

Aspen-brush

Open

Jack pine

Aspen

Aspen

Red pine -60 sq. ft. basal area per acre Red pine-140 sq. ft. basal area per acre Open

Black spruce uncut

Black spruce selection

Black spruce shelterwood

Black spruce clear-cut patch

Black spruce clear-cut strip

\section{METHODS}

At each plot, 10 sampling points were laid out and frost and snow data collected on each date of observation. The observations of snow accumulation and melt were published previously (Weitzman and Bay 1959), so this report will be confined largely to frost measurements - although both were collected concurrently.

After the first of each year, frost measurement was started and carried on into spring until the frost had completely left the ground. Measurements were taken at intervals of about 3 weeks except during the melt period when the intervals were closer.

On each sampling date, frost type and depth were recorded. Frost type was identified by chop- ping small pits. Depth was measured directly. Several types of frost were recognized, not all of which prevent the infiltration of water. In comparison to concrete frost, other forms known as granular, stalactite, honeycomb, and porous-concrete are much more permeable and less likely to cause excessive surface erosion (Dreibelbis 1949, Post and Dreibelbis 1942). Since the purpose of this study was to determine the hydrologic significance of frost, only concrete frost, which is least permeable to the passage of water, is reported. The frequency of occurrence is an average of all observations, whether or not concrete frost was present. The frost depths are an average of the inches of frost observed whenever it was present. 
Where the frost was deep, a penetrometer was used and pounded to a depth of 10 inches (Stoeckeler and Thames 1958). Beyond that depth the penetrometer often bent, thus limiting the depth

The results of this study may be logically explained in simple terms. Soil freezing requires two basic ingredients - free water and freezing temperature. When the effects of cover type, soil texture, and snow depth on these two ingredients are examined, the reasons for variations in soil freezing are more apparent. Although other factors are involved (Anderson 1946, Tsytovich and Sumgin 1937), they do not prevent a firm interpretation of results.

The factors studied are divided into two broad groups - natural factors, over which we have no control, and management factors, which land managers can manipulate.

\section{Natural Factors}

Climate and soil play a major role in soil freezing through their effect on available soil moisture and soil temperatures. Although we have no control over these factors, their influence must be understood to show the framework within which management can operate.

\section{Effect of Snow Depth}

Under similar temperature conditions, the depth of snow strongly influences the amount of freezing. Snow is a good insulator. The very slow heat exchange between the atmosphere and the ground protected by snow is a result of poor heat conduction by the snow mantle. The deeper the snow, the more effective the insulation (Anderson 1947, Molchanov 1950).

Previous studies have indicated a correlation between snow depth and the occurrence and depth of concrete frost (Atkinson and Bay 1940, Sartz 1957, Scholz 1938 ). Most of these, however, were made on areas of different forest covers - or in different years. of observation. Available time and value of data did not justify deeper hand excavations. Throughout the 2 years about 2,800 frost observations were made.

\section{RESULTS}

The direct influence of snow on freezing was observed under identical conditions and cover during the winter of 1958. Six subplots were laid out in each of two cover types - an aspen stand and a red pine stand. On three subplots all snow was shovelled off; the other three remained undisturbed and snow was allowed to accumulate. Maximum snow accumulation reached only 10 inches. The difference in frost depth between the two treatments was tested on the last date shown, since this is the time of the year when frost is most important hydrologically; i.e., during spring breakup. The depth of concrete frost was significantly less (at the 5-percent level) in the undisturbed stands than in those where the snow had been removed (table 1 ).

TABLE 1. - Average depth of concrete frost with and without snow cover (In inches)

\begin{tabular}{l|cc|cc}
\hline \multirow{2}{*}{ Date } & \multicolumn{2}{|c|}{ Snow removed } & \multicolumn{2}{c}{ Undisturbed } \\
\cline { 2 - 5 } & Aspen & Red pine & Aspen & Red pine \\
\hline Dec. 17, 1957 & 0.7 & 4.4 & 0.4 & 3.9 \\
Feb. 4, 1958 & $10+$ & $10+$ & 5.0 & $10+$ \\
Mar. 12, 1958 & $10+$ & $10+$ & 7.8 & 7.0 \\
Apr. 3, 1958 & $10+$ & $10+$ & 5.9 & 5.5 \\
\hline
\end{tabular}

Although snow accumulation is listed as a natural factor, the forest manager can manipulate to some degree the depth of snow that accumulates. Practices such as thinning conifers and planting alterriate belts of mixed conifers and hardwoods will increase the amount of snow accumulated on the ground and thus help reduce soil freezing.

\section{Effect of Soil Texture on Freezing}

Most studies of freezing have concentrated on cover effects almost entirely, with no stratification by forest soils. Actually, soil texture affects moisture available for freezing, just as snow and forest cover modify temperature (Surmach 1955 ). 
Since both moisture and temperature are equally important in freezing, a knowledge of soils helps explain the type and depth of freezing. Table 2 shows for 2 years the difference in frost occurrence under two soils of different texture. In both years there was more freezing in the heavier textured soil. It is suggested that texture modifies the amount of water held in pore space and limits availability of water for freezing. Sandy soils will freeze rapidly but, because water may be lacking, will not always form an impervious concrete frost in northern Minnesota. Silt loams, on the other hand, hold two to three times as much water. This becomes available for freezing under the right temperature conditions. As a result, concrete frost, which is a mass of consolidated ice crystals, forms throughout this type of soil mantle.

\section{TABLE 2. - Frequency of conerete frost by soil texture and eover (In pereent)}

\begin{tabular}{|c|c|c|c|c|}
\hline \multirow[b]{2}{*}{ Year } & \multicolumn{2}{|c|}{ Very fine sandy loam } & \multicolumn{2}{|c|}{ Loamy fine sand } \\
\hline & $\begin{array}{l}\text { Aspen } \\
\text { stand }\end{array}$ & $\begin{array}{l}\text { White pine } \\
\text { stand }\end{array}$ & $\begin{array}{l}\text { Aspen } \\
\text { stand }\end{array}$ & $\begin{array}{l}\text { Jack pine } \\
\text { stand }\end{array}$ \\
\hline 1957 & 68 & 53 & 5 & 6 \\
\hline 1958 & 45 & 50 & 10 & 25 \\
\hline
\end{tabular}

In this study a different type of frost was recognized. This type is almost as hard as concrete frost, but crumbles when dug into or chopped. The soil is hard but is not cemented together intr a concrete-like mass by frozen ice crystals. One possible explanation is that an extremely low moisture content in sandy soils may prevent the formation of solid concrete frost. Pore spaces may be so large and moisture content so low that the ice crystals cannot form a continuous frozen lens.

This explanation is supported by the data on moisture content of frost types shown in table 3 .
Although the data vary considerably, the trend from low moisture content of nonfrozen soil to medium for dry concrete and extremely high for concrete frost is evident. A similar relationship was observed and reported in a companion study of infiltration in frozen soils (Stoeckeler and Weitzman 1960).

The combination of low local precipitation (average annual 25 inches) plus the low waterholding capacity of sandy soil is probably the reason for less concrete freezing in this area. Where precipitation is higher, there is apparently enough moisture even in sandy soils to freeze solidly (Striffler 1959).

The occurrence of dry or porous concrete frost varies with the precipitation pattern within any one year. For example, less of this frost type was recognized in the winter of 1958 because more rain fell and soil moisture was higher in the fall of 1957 prior to freezing than in 1956 .

\section{Freezing in Organic Soils}

Freezing in organic soils has received very little study. Current tests in black spruce stands, both cut and uncut, indicate that peat soils probably follow the same freezing pattern as mineral soils. These observations were made on only one peat type. The peat was derived mostly from mosses, wood, and other plants. "Feather" mosses dominated the ground cover before cutting. Decomposition increased with depth below the surface. The ground water table was normally 6 to 30 inches below the surface. Peat depth averaged approximately 4 to 5 feet in the area.

It is logical to surmise that there is a range of conditions that modifies frost behavior in organic soils just as in mineral soils. Type of peat, depth to water table, and rate of flow through the peat

TABLE 3. - Moisture content of frost types in sandy soils, $195 \%$

(In pereent by weight)

\begin{tabular}{|c|c|c|c|c|c|c|}
\hline \multirow{3}{*}{ Cover type } & \multicolumn{6}{|c|}{ Frost type and date of measurement } \\
\hline & \multicolumn{2}{|c|}{ Nonfrozen } & \multicolumn{2}{|c|}{ Dry concrete } & \multicolumn{2}{|c|}{ Concrete frost } \\
\hline & Mar. 18 & Mar. 26 & Mar. 18 & Mar. 26 & Mar. 18 & Mar. 26 \\
\hline Open plot & $(1)$ & (1) & 11.4 & 16.2 & 32.5 & 35.6 \\
\hline Aspen stand & 7.5 & 7.1 & 23.5 & 16.5 & 53.8 & $(1)$ \\
\hline $\begin{array}{l}\text { Red pine stand } \\
\quad(60 \text { sq. ft. B.A.) }\end{array}$ & 8.6 & 12.5 & 21.4 & 15.1 & 33.8 & 54.6 \\
\hline $\begin{array}{l}\text { Red pine stand } \\
\quad(140 \mathrm{sq} \text {. ft. B.A.) }\end{array}$ & (1) & 9.1 & 12.2 & 21.6 & 27.4 & 45.1 \\
\hline
\end{tabular}


bog all affect the heat exchange and probably the moisture in the upper horizons, both of which will affect the type of freezing. However, for the two seasons studied, the seasonal pattern of freezing followed the same trends as that of mineral soil.

Figure 1 compares the trends of concrete frost depth between February and April, 1958, under dense black spruce on peat, white pine on loam, and aspen on sand. In general, the patterns of freezing and thawing were similar. Frost in the peat, however, remained much longer than in mineral soil. There was still frost in the bog at the time of the last observation. Pieces of solid ice were found in late May and early June.

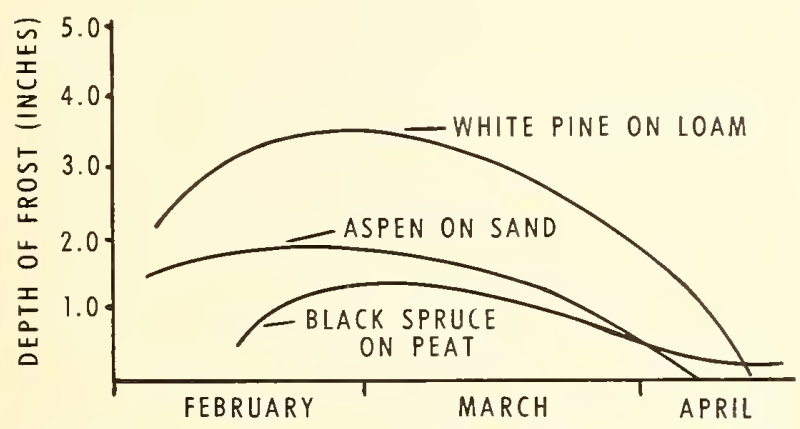

Figure 1. - Freezing pattern shows similar trend on mineral and organic soil; winter, 1958.

\section{Management Factors}

The natural factors, such as climate and soils, provide the framework within which freezing occurs. However, foresters manipulate other factors that can influence the free water and freezing temperatures and thus influence depth, type, and duration of freezing.

The effect of conventional forest treatments on soil freezing remains largely unexplored. Yet this is one of the few tools that foresters have to modify frost depth and duration. This study gives some indications on how the manipulation of cover will influence freezing.

\section{Forest Versus Open}

The advantages of forest cover over open land in reducing freezing are well established (Kienholtz 1940, Lull and Pierce 1961). The present observations show a similar trend (tables 4,5 , and $6)$.
TABLE 4. - Depth of concrete frost during midwinter period (January to mid-March) on loamy soils (In inches)

\begin{tabular}{lcc}
\hline \multicolumn{1}{c}{ Cover type } & 1957 & 1958 \\
\hline Open plot & $10 \div$ & $10+$ \\
Forested plots & 4.6 & \\
Aspen (80 sq. ft. B.A.) & 3.7 & 6.6 \\
Aspen (65 sq. ft. B.A.) & 3.2 & 5.8 \\
White pine-hardwood & 7.4 & $10 \div$ \\
Balsam fir & 6.4 & $10+$ \\
Red pine plantation & 3.6 & 6.4 \\
Aspen-brush & \\
\hline
\end{tabular}

TABLE 5. - Frequency of occurrence of concrete frost on sandy soils (In percent)

\begin{tabular}{lcc}
\hline \multicolumn{1}{c}{ Cover type } & 1957 & 1958 \\
\hline Open plot & 87 & 100 \\
Forested plots & 47 & 73 \\
Aspen & 44 & 66 \\
Red pine, 60 sq. ft. B.A. & 47 & 63 \\
Red pine, 140 sq. ft. B.A. & \\
\hline
\end{tabular}

TABLE 6. - Depth and frequcncy of concrete frost in black spruce bog, $195 \%$

\begin{tabular}{lcc}
\hline Treatment & Depth & Frequency \\
\hline Open plots & Inches & Percent \\
Clear-cut patch & 3.4 & 77 \\
Clear-cut strip & 3.7 & 68 \\
Shelterwood & 3.5 & 58 \\
\cline { 2 - 3 } Arerage & 3.5 & 68 \\
Forested plots & & \\
Tree selection & 2.0 & 35 \\
Check & 1.5 & 17 \\
Average & 1.7 & 26 \\
\hline
\end{tabular}

The influence of forest openings on depth and duration of freezing in peatland is also very pronounced (table 6 ). In the three openings created in a black spruce bog, concrete frost occurred three times as often and was twice as deep as in the two test areas under forest cover.

\section{Comparison of Cover Types}

On loamy soils, the lowest incidence and the shallowest depth of frost were found under a mixed white pine-hardwood stand (table 4 ). This mixed stand had the deepest humus and the deepest accumulation of snow. These two factors both provide insulation against extreme soil temperatures and probably were responsible for the lower incidence of frost (MacKinney 1929, Striffler 1959). 


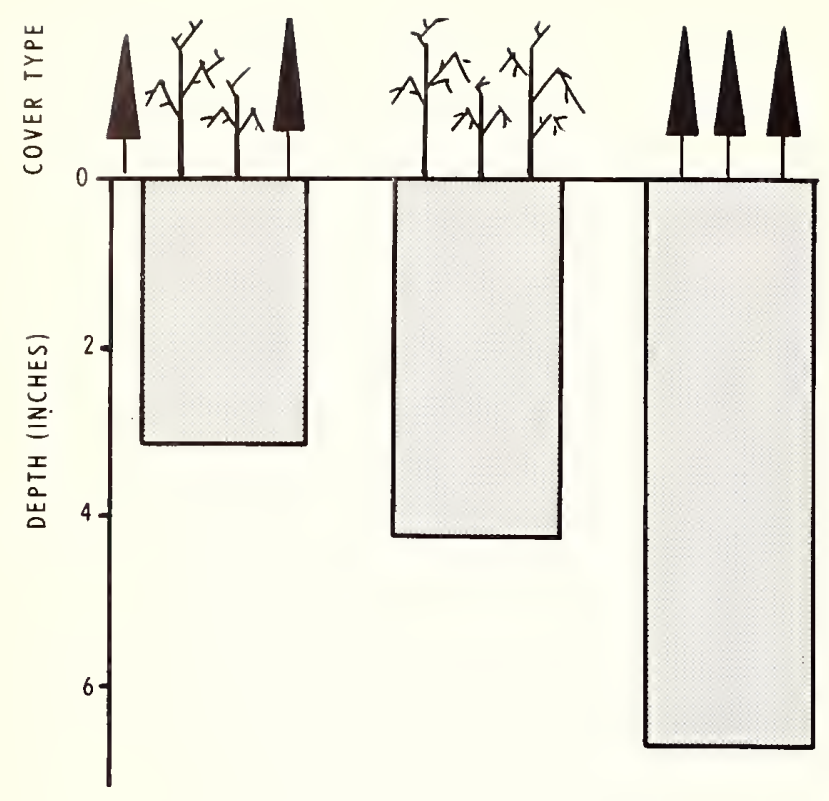

WHITE PINEHARDWOOD

ASPEN

RED PINE PLANTATION

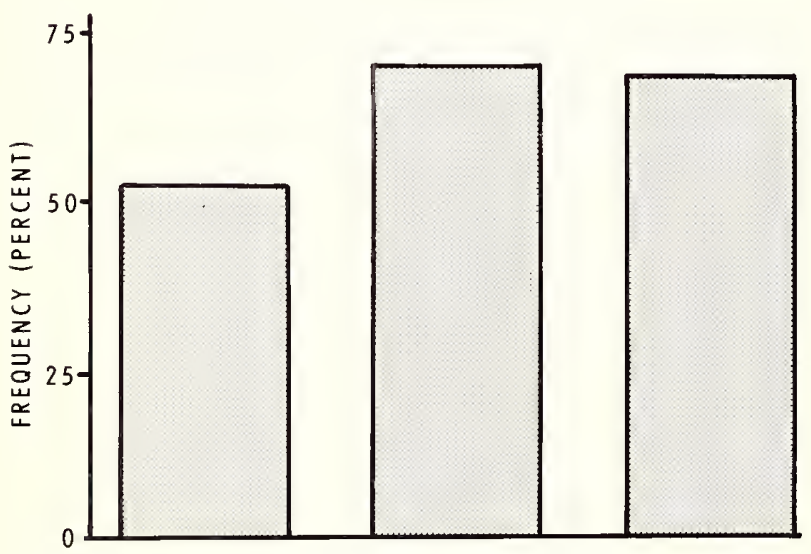

Figure 2. - Average depth and frequency of concrete frost under several cover types on loamy soils (1957).

TABLE 7. - Depth and occurrence of concrete frost under two levels of red pine stocking, 195\%

\begin{tabular}{l|cc|cc}
\hline \multirow{2}{*}{ Date } & $\begin{array}{c}\text { Thinned stand } \\
(60 \text { sq. ft. basal area })\end{array}$ & \multicolumn{2}{|c}{$\begin{array}{c}\text { Unthinned stand } \\
(140 \text { sq. ft. basal area })\end{array}$} \\
\cline { 2 - 5 } & Depth & Occurrence & Depth & Occurrence \\
\hline & Inches & Percent & Inches & Percent \\
Jan. 7 & 4.4 & 100 & 6.5 & 100 \\
Feb. 4 & 1.3 & 70 & 3.5 & 40 \\
Feb. 18 & 1.7 & 60 & 3.0 & 60 \\
Mar. 4 & 1.1 & 60 & 1.8 & 80 \\
Mar. 18 & 1.9 & 90 & 1.9 & 70 \\
Mar. 25 & 1.7 & 30 & 1.7 & 50 \\
Apr. 1 & 1.3 & 30 & 1.7 & 50 \\
Apr. 8 & 0 & 0 & 2.1 & 40 \\
Apr. 15 & 0 & 0 & 1.7 & 20 \\
Average & 1.9 & 49 & 2.6 & 57 \\
\hline
\end{tabular}

A pure pine planting, on the other hand, showed a greater depth of concrete freezing than either the mixed stand or pure aspen (table 4 and fig. 2). The incidence of concrete frost was lowest in the mixed stand and somewhat higher in both pure pine and aspen. Establishing a pure conifer planting on open, plowed, or burned-over land must be recognized as only the first step in soil amelioration. The pure conifer planting may be better than open-land areas, but not as good as the natural hardwood or mixed pine-hardwood forest.

\section{Effect of Thinning in Dense Conifers}

On sandy soils there was a slight decrease in depth of frost under a pine stand after thinning (table 7 ). The reason for the difference probably lies in the increased depth of snow accumulated in a thinned stand. Since snow is a good insulator, the temperature at soil level is higher, and hence the freezing is reduced.

Thinning dense conifers is accepted as a sound management practice. This study indicates that it may have some hydrologic benefits as well. The thinned pine stand accumulated more snowfall and had less frost depth to impede water infiltration into the ground.

\section{Effect of Thinning in Aspen}

A thinned aspen stand on loamy soil also showed a small reduction in frost - both depth and occurrence (table 8 ). The difference again was not large, and the same factors were probably involved.

'TABLE 8. - Dcpth and occurrence of concrcte frost under two aspen stands with differcnt lcvels of stocking, 1957

\begin{tabular}{l|cc|cc}
\hline \multirow{2}{*}{ Date } & \multicolumn{2}{|c|}{65 sq. ft. basal area } & \multicolumn{2}{c}{80 sq. ft. basal area } \\
\cline { 2 - 5 } & Depth & Occurrence & Depth & Occurrence \\
\hline \multirow{2}{*}{ Jan. 9} & Inches & Percent & Inches & Percent \\
Feb. 5 & 4.8 & 70 & 1.9 & 90 \\
Feb. 19 & 2.2 & 80 & 4.2 & 100 \\
Mar. 4 & 3.5 & 90 & 5.1 & 100 \\
Mar. 22 & 5.9 & 90 & 6.5 & 100 \\
Apr. 41 & 2.7 & 70 & 5.4 & 100 \\
Average & 3.5 & 83 & 4.5 & 90 \\
\hline
\end{tabular}

1 On the next date of measurement, April 11, no frost was found. 
The study indicates that snow depth, soil texture, and cover type and density are related to depth and duration of soil freezing. Many other factors must be studied before the full and composite effect of forest cover and its manipulation are understood. Nevertheless, the results of these observations indicate the conditions that reduce ground freezing and thus provide an opportunity for water to enter the soil rather than run off in spring freshets.

1. Frost depth and duration varied from year to year, depending on natural climatic factors such as moisture in soil and snow depths.

2. Sandy textured soils had less concrete freezing than fine-textured soils that retain more water.

3. The pattern of freezing in an organic soil

Anderson, H. W.

1946. The effect of freezing on soil moisture and on evaporation from bare soils. Amer. Geophys. Union Trans. 27: 863870.

Anderson, H. W.

1947. Soil freezing and thawing as related to some vegetation, climatic, and soil variables. Jour. Forestry 45: 94-101.

Atkinson, H. B., and Bay, C. E.

1940. Some factors affecting frost penetration. Amer. Geophys. Union Trans. 9: 935-948.

Augustine, M. T.

1941. Infiltration runs on frozen ground. Soil Sci. Soc. Amer. Proc. 6: 435.

Bay, C. E., Wunnecke, G. W., and Hays, Orville E.

1952. Frost penetration into soils as influenced by depth of snow, vegetative cover, and air temperatures. Amer. Geophys. Union Trans. 33: 541-546.

Bay, R. R.

1960. Soil freezing observations after changes in forest cover. U.S. Forest Serv., Lake States Forest Expt. Sta. Tech. Note 576, $2 \mathrm{pp}$. was similar to that of mineral soils, but frost lasted much longer in organic material.

4. Thinning in a conifer and a hardwood stand slightly reduced the depth and duration of frost, largely because of a greater accumulation of snow which acts as an insulator.

5. Freezing under hardwoods was less severe than under conifers.

6. A mixed stand of scattered conifers and hardwoods (white pine-hardwoods) combined the advantages of the lowest incidence of frost and the greatest accumulation of snow. Thus a mixed stand is more desirable than pure stands of either pine or hardwoods for reducing frost.

7. Open areas had greater depth and duration of concrete frost than forested areas.

\section{- literAtURE CITED}

Coleman, E. A.

1953. Vegetation and watershed management. 412 pp., illus., New York.

Cunningham, R. N., Horn, A. G., and Quinney, D. N. 1958. Minnesota's forest resources. U.S. Dept. Agr. Forest Resource Rept. 13, 53 pp., illus.

Dreibelbis, F. R.

1949. Some influences of frost penetration on the hydrology of small watersheds. Amer. Geophys. Union Trans. 30: 279-282.

Hale, Charles E.

1950. Some observations on soil freezing in forest and range lands of the Pacific Northwest. U.S. Forest Serv., Pacific Northwest Forest Expt. Sta. Res. Note 66, 17 pp., illus.

Kienholz, Raymond.

1940. Frost depth in forest and open in Connecticut. Jour. Forestry 38: 346-350.

Lull, Howard S., and Pierce, R. S.

1961. Frost and forest soil. Symposium of Hanoversch-Munden, Water and Woodlands I: $40-48$. 
MacKinney, A. L.

1929. Effect of forest litter on soil temperature and soil freezing in autumn and winter. Ecol. 10: 312-321.

Molchanov, A. A.

1950. Freezing and thawing of soil. Lesnoe Khoziaistro 3(1): 27-31. Translated by J. A. Bender, 1951, for Corps of Engineers, U.S. Army, SIPRE, Wilmette, Ill.

Post, F. A., and Dreibelbis, F. R.

1942. Some influences of frost penetration and microclimate on the water relationship of woodland, pasture, and cultivated soils. Soil Sci. Soc. Amer. Proc. 7: 95-104.

Sartz, Richard S.

1957. Influence of land use on time of soil freezing and thawing in the Northeast. Jour. Forestry 55: 716-718.

Scholz, H. F.

1938. Forest cover keeps frost line at shallow depth. Jour. Forestry 36: 78-79.

Stoeckeler, J. H., and Thames, J. L.

1958. The Lake States penetrometer for measuring depth of soil freezing. Soil Sci. 85: $47-50$.

Stoeckeler, J. H., and Weitzman, S.

1960. Infiltration rates in frozen soil in northern Minnesota. Soil Sci. Soc. Amer. Proc. 24: 137-139.

Storey, Herbert C.

1955. Frozen soil and spring and winter floods. U.S. Dept. Agr. Yearbook 1955: 179-184.
Striffler, W. D.

1959. Effects of forest cover on soil freezing in northern Lower Michigan. U.S. Forest Serv., Lake States Forest Expt. Sta., Sta. Paper 76, 16 pp., illus.

Surmach, G. P.

1955. Conditions determining the absorption of spring snow water by the soil. Zemledie 3: 8-12. (Translation No. 376 by U.S. Forest Serv., 6 pp.)

Trimble, G. R. Jr., Sartz, R. S., and Pierce, R. S.

1958. How type of soil frost affects infiltratration. Jour. Soil and Water Conserv. 13(2): 81-82.

Tsytovich, N. A., and Sumgin, M. I.

1937. Principles of mechanics of frozen ground (Osnovaniia Mekhaniki merzlyth gruntov). Izdatel'stro Akademii Nauk USSR. Translation 19, April 1959, U.S. Army, SIPRE, Corps of Engineers, Wilmette, Ill., 288 pp., illus.

U. S. Department of Interior.

1953. Floods of 1950 in the Upper Mississippi River and Lake Superior Basins in Minnesota. Geol. Survey Water-Supply Paper 1137-G, pp. 791-895, illus.

Weitzman, S., and Bay, R. R.

1959. Snow behavior in forests of northern Minnesota and its management implications. U.S. Forest Serv., Lake States Forest Expt. Sta., Sta. Paper 69, 18 pp., illus. 


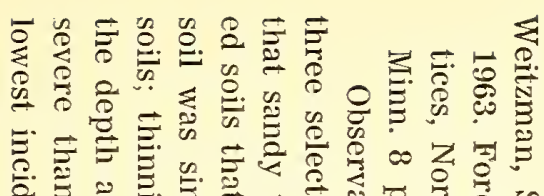

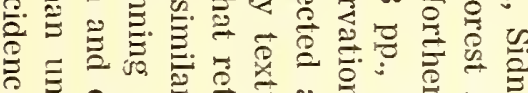

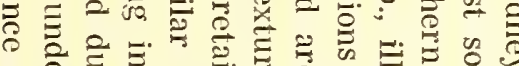

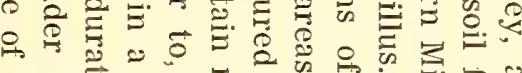

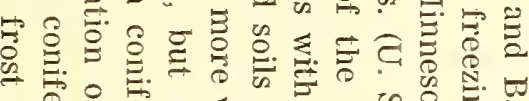

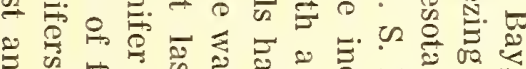

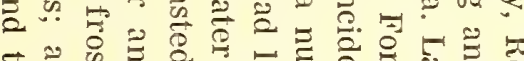
후을

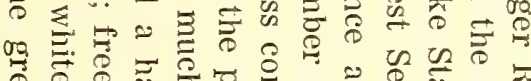

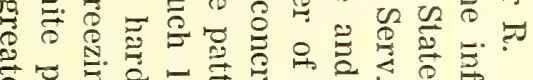

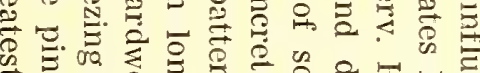
空

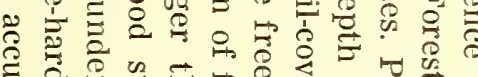

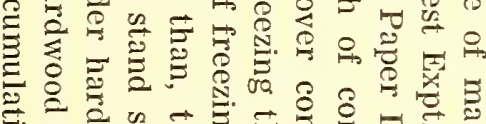

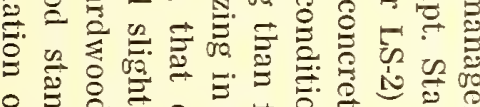

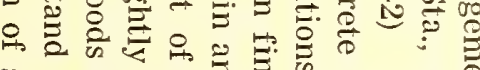

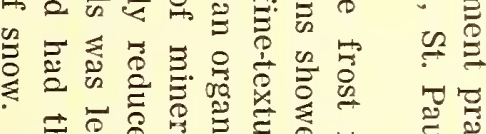

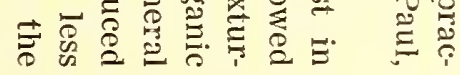

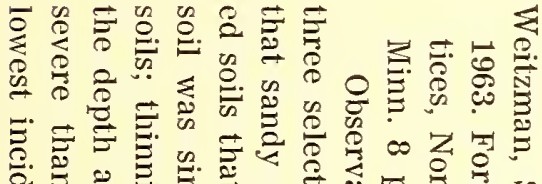

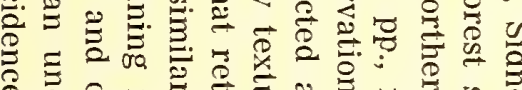

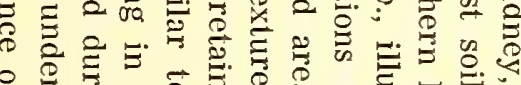

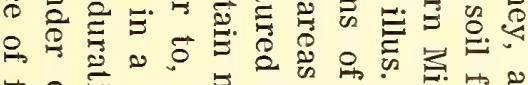

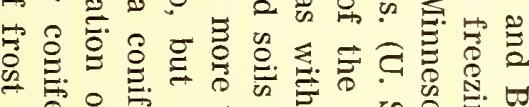

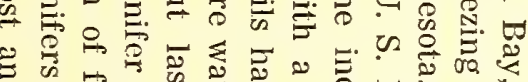

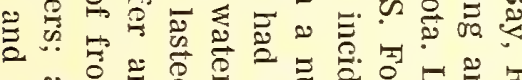

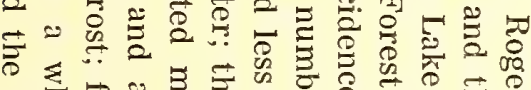

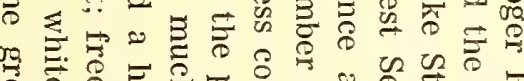

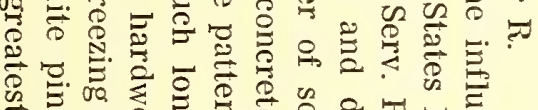

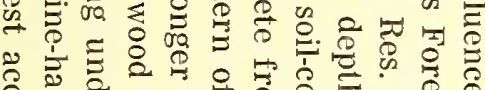

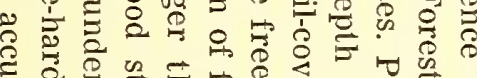

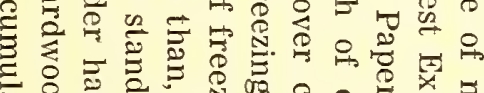

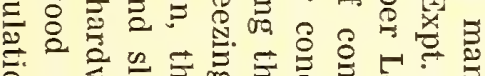

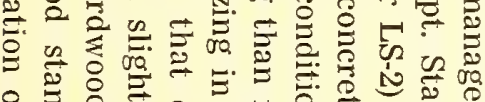

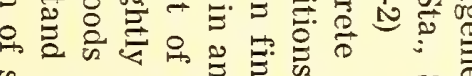

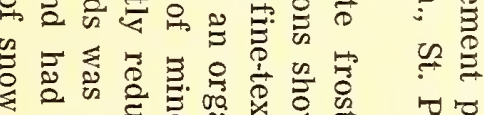

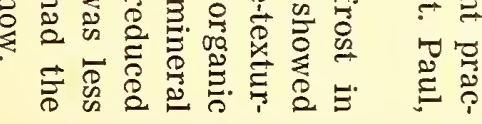

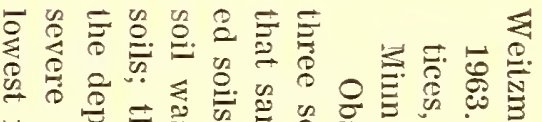

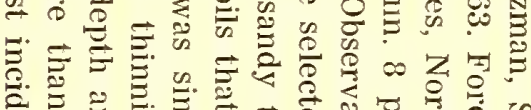

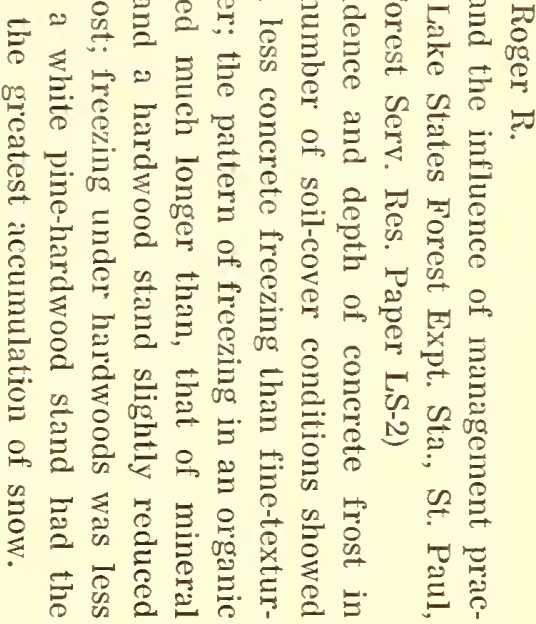

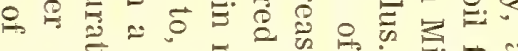

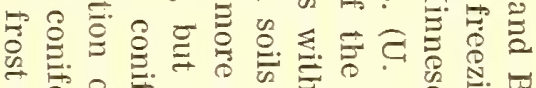

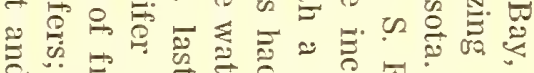

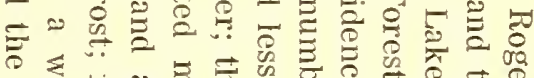

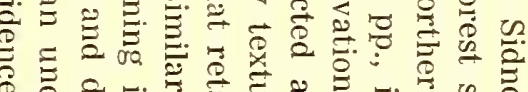

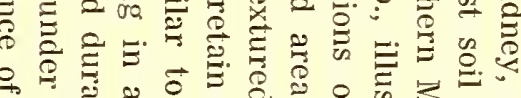

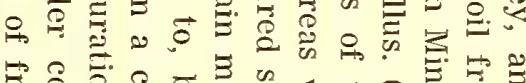

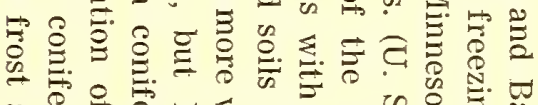

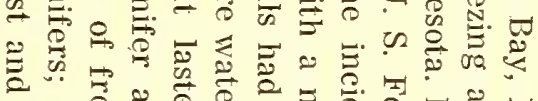

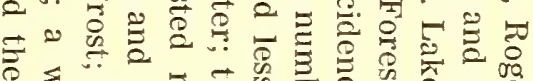

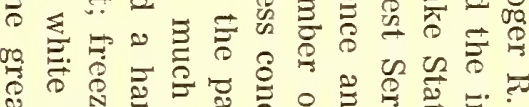

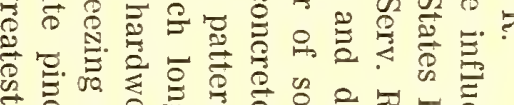

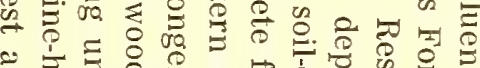

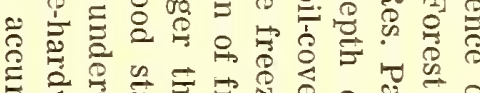

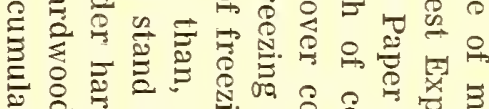

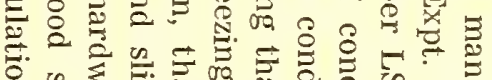

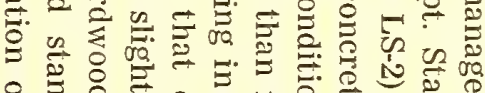

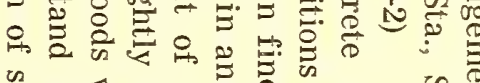

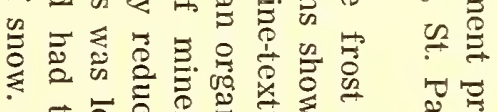

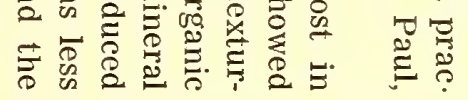





\section{SOME RECENT STATION PAPERS}

Field Calibration of a Neutron-Scattering Soil Moisture Meter, by Richard S. Sartz and Willie R. Curtis. Sta. Paper 91, 15 pp., illus. 1961.

Growing White Pine in the Lake States to Avoid Blister Rust, by Eugene P. Van Arsdel, Sta. Paper 92, 11 pp., illus. 1961.

Farm Lumber Consumption and Use Data: Needs and Methods of Estimating, by Allen L. Lundgren and Ronald I. Beazley. Sta. Paper 93, 20 pp., illus. 1961.

Pulpwood Production in Lake States Counties, 1960, by Arthur G. Horn, Sta. Paper 94, 28 pp., illus. 1962.

Small Private Forest Landowners in Michigan's Upper Peninsula - Characteristics, Ownership Attitudes, and Forestry Practices, by Dean N. Quinney. Sta. Paper 95, 20 pp., illus. 1962.

Contracting for Forest Aerial Photography in the United States, by Gene Avery and Merle P. Meyer. Sta. Paper 96, 37 pp., illus. 1962.

Three Pine Release Experiments in Northern Minnesota, by Robert E. Buckman and Allen L. Lundgren. Sta. Paper 97, 9 pp., illus. 1962.

Proceedings of the Fifth Lake States Forest Tree Improvement Conference. Sta. Paper 98, 42 pp. 1962.

Three Growing Stock Density Experiments in Minnesota Red Pine - A Progress Report, by Robert E. Buckman. Sta. Paper 99, 10 pp., illus. 1962.

Identification of Conifer Insects by Type of Tree Injury, Lake States, by H. J. MacAloney and D. C. Schmiege. Sta. Paper 100, 41 pp., illus. 1962.

Forest Insects and Diseases in the Northern Great Plains - A Survey, by Louis F. Wilson, Sta. Paper 101, 28 pp., illus. 1962.

Forest Plantations of Northern Lower Michigan, by Robert N. Stone and Clarence D. Chase. Sta. Paper 102, 31 pp., illus. 1962.

Private Forest Landownership in the Urban Fringe Area of Michigan, by Con H. Schallau. Sta. Paper 103, 17 pp., illus. 1962.

The Market For Wood Pallets in the Auto Industry - A Case Study of Ford Motor Company, by Charles F. Sutherland, Jr. Sta. Paper 104, 10 pp., illus. 1962.

Site Requirements and Yield of Paper Birch in Northern Wisconsin, by John H. Cooley. Sta. Paper 105, 11 pp., illus. 1962.

Pulpwood Prociuction in Lake States Counties, 1961, by Arthur G. Horn. Sta. Paper 106, 18 pp., illus. 1962. 


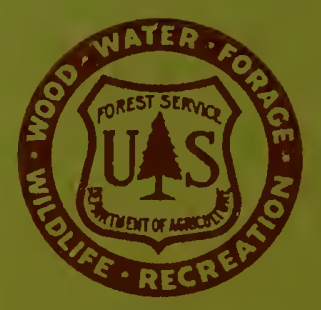

